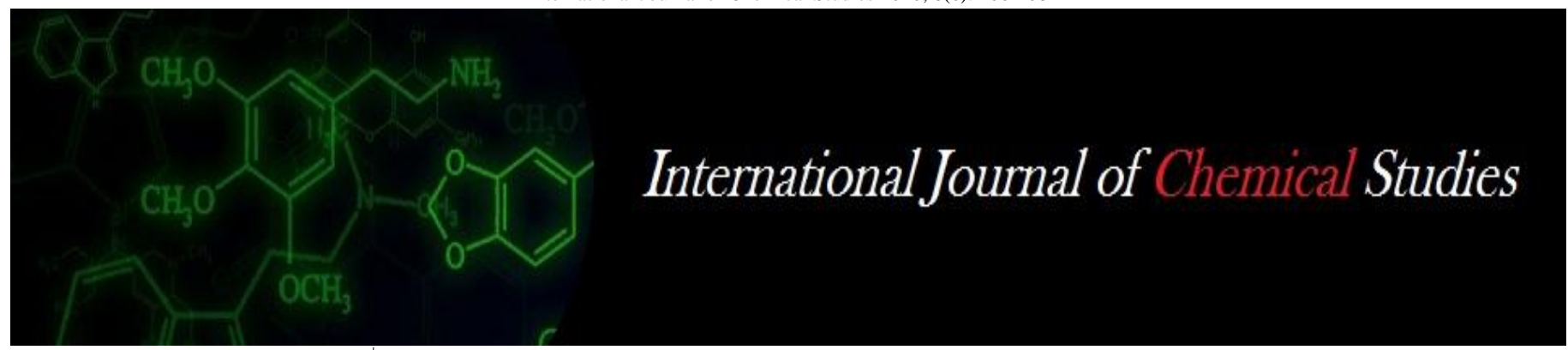

P-ISSN: 2349-8528

E-ISSN: 2321-4902

www.chemijournal.com

IJCS 2020; 8(6): 206-208

(C) 2020 IJCS

Received: 06-09-2020

Accepted: 18-10-2020

Vinay Verma

Department of Horticulture

SVPUAT, Meerut, Uttar

Pradesh, India

Shalini Singh

Department of Horticulture

SVPUAT, Meerut, Uttar

Pradesh, India

Corresponding Author:

Vinay Verma

Department of Horticulture,

SVPUAT, Meerut, Uttar

Pradesh, India

\section{Correlation and path coefficient analysis of quantitative characters in okra [Abelmoschus esculentus (L.) Moench.]}

\author{
Vinay Verma and Shalini Singh
}

DOI: https://doi.org/10.22271/chemi.2020.v8.i6c.10771

\begin{abstract}
Fifty genotypes of okra were evaluated in a randomized block design with three replications during kharif 2016-17 at Horticulture Research Centre, SVPUAT, Modipuram, Meerut to study the correlation and path analysis for its yield and contributing traits. The difference between genotypic and phenotypic correlation coefficient indicates the influence of environmental effects. The highest significant positive correlation were observed between number of fruits per plant and yield per plant $\left(r=0.660^{* *}\right)$. Significantly positive correlations were also observed for number of branches per plant and length of first fruiting node $\left(\mathrm{r}=205^{*}\right)$ plant height and number of first fruiting node $\left(\mathrm{r}=198^{*}\right)$, number of branches per plant and number of fruits per plant $\left(\mathrm{r}=190^{*}\right)$ these relations were also found to be significant in genotypic level. Plant height and length of internode, length of internode and length of fruit, length of first fruiting node and width of fruit and length of fruit and width of fruit were also found significant in genotypic level. The path coefficient analysis was done to determine direct and indirect effects of traits on fruit yield. Direct positive effect on fruit yield per plant was observed by number of fruits per plant, followed by number of branches per plant, plant height, length of internode and number of first fruiting node.
\end{abstract}

Keywords: Correlation, path analysis, quantitative characters, okra, yield components

\section{Introduction}

Okra [Abelmoschus esculentus (L.) moench] is popularly known as lady's finger or Bhindi. It is the only vegetable crop of significance in the Malvaceae family. It is extensively grown in temperate, subtropical and tropical regions of the world (Kochhar, 1986) ${ }^{[7]}$. Okra occupies fifth position, next to tomato, in area under vegetables in the country. Okra is mainly grown for tender fruits which are used as vegetable. Fruits are used in curry and soups after cooking. Fruits are rich in vitamin $\mathrm{A}$ and $\mathrm{C}$, riboflavin, and minerals like calcium, phosphorus, iodine, iron and potassium (Gopalan et al., 1991) ${ }^{[4]}$. It is actually a potential export earner which provides high return to the growers. Its fruits have high nutritive, medicinal and industrial value and export potential. Its fruits are rich in vitamins, calcium, potassium and other mineral matters (Camciuc et al., 1981) ${ }^{[2]}$. Okra seed oil is rich in unsaturated fatty acids such as linoleic acid (Savello et al., 1980) ${ }^{[10]}$, which is essential for human nutrition.

Correlation and path coefficient analyses are prerequisites for improvement of any crop including okra for selection of superior genotypes and improvement of any trait. (Johanson et al, 1995) pointed out that genotypic correlation coefficient provide a measure of association between characters at genotypic level and give an indication of the characters that may be useful as the indicators of the more important as under consideration The correlation studies simply measure the associations between yield and other traits. Usefulness of the information obtained from the correlation coefficients can be enhanced by partitioning into direct and indirect effects for a set of a pair-wise cause-effect inter relationships (Kang et al., 1983) ${ }^{[6]}$. Path coefficient analysis permits the separation of correlation coefficient into direct and indirect effects. It is basically a standardized partial regression analysis and deals with a closed system of variables that are linearly related. Such information provides a realistic basis for allocation of appropriate weightage to various yield components. (Dewey and Lu, 1959) ${ }^{[3]}$ for the first time applied the technique of path coefficient to plant breeding and reported that it provides important information about the specific forces acting to produce a particular correlation. 


\section{Material and Methods}

The experimental material of the present investigation comprising fifty genotypes of okra were evaluated in a randomized block design with three replications during kharif 2016-17 at Horticulture Research Centre, Sardar Vallabhbhai Patel University of Agriculture and Technology, Meerut, U.P. Observations were recorded on five competitive plants for days to flowering, plant height $(\mathrm{cm})$, number of branches per plant, length of first fruiting node $(\mathrm{cm})$, number of first fruiting node, Length of internode $(\mathrm{cm})$, length of fruit $(\mathrm{cm})$, width of fruit $(\mathrm{cm})$, number of fruits per plant and yield per plant $(\mathrm{g})$. Correlation coefficients were calculated for all quantitative character combinations at phenotypic, genotypic and environmental levels, method suggested by Panse and Sukhatme (1967) ${ }^{[8]}$ and path coefficient were worked out as per the method given by Wright (1921) ${ }^{[15]}$ and elaborated by Dewey and Lu (1959) ${ }^{[3]}$.

\section{Results and Discussion}

Analysis of variance showed that genotypes differed significantly among themselves for all the traits studied in the present investigation. The genotypic and phenotypic correlation coefficients worked out among ten characters (table-1) revealed that in general, genotypic correlation coefficient was higher than the phenotypic correlation coefficients indicating a strong inherent association between various traits. In some cases the phenotypic correlation coefficient was higher than the genotypic correlation coefficient which may be a result of modifying effect of environments on the association of the traits. Yield per plant exhibited positive and significant correlation with number of fruits per plant $(660,707)$, plant height $(198,188)$ and number of branches per plant. Similar results were obtained by Singh and Goswami (2014) ${ }^{[11]}$, Swamy et al. (2014) ${ }^{[12]}$, Sharma and Prasad (2015) ${ }^{[13]}$. Phenotypic and genotypic path coefficient (Table-2) exhibited high positive direct contribution of number of fruits per plant $(0.643,0.727)$, length of internode $(0.029,0.109)$, plant height $(0.034,0.021)$ towards yield per plant. High indirect positive contribution of days to flowering via length of fruit $(0.058,0.035)$; plant height via number of fruits per plant $(0.030,0.006)$, length of internode $(0.003$, $0.019)$, number of branches per plant $(0.029,0.010)$; number of branches per plant via number of fruits per plant $(0.013$, 0.187 ); length of first fruiting node via number of branches per plant $(0.017,0.005)$, plant height $(0.007,0.004)$ and days to flowering $(0.003,0.001)$; number of first fruiting node via length of fruit $(0.048,0.068)$; length of internode via days to flowering $(0.015,0.014)$, plant height $(0.004,0.003)$; length of fruit via days to flowering $(0.019,0.005)$, length of internode $(0.004,0.020)$; width of fruit via days to flowering $(0.009,0.007)$, number of branches per plant $(0.035,0.005)$, length of internode $(0.005,0.017)$ and number of fruits per plant $(0.006,0.025)$; number of fruits per plant via number of branches per plant $(0.020,0.005)$. These results are in general agreement with the findings of Swamy et al. (2014) ${ }^{[12]}$, Balai et al. (2014) ${ }^{[1]}$, Ramanjinappa et al. $(2011)^{[9]}$.

Table 1: Estimation of correlation coefficient for phenotypic (PC) and Genotypic (GC) levels among different characters in okra

\begin{tabular}{|c|c|c|c|c|c|c|c|c|c|c|c|}
\hline Characters & & $\begin{array}{c}\text { Days to } \\
\text { flowering }\end{array}$ & $\begin{array}{c}\text { Plant } \\
\text { height } \\
(\mathrm{cm})\end{array}$ & $\begin{array}{l}\text { Number of } \\
\text { branches } \\
\text { per plant }\end{array}$ & $\begin{array}{c}\text { Length of } \\
\text { first fruiting } \\
\text { node }(\mathrm{cm})\end{array}$ & \begin{tabular}{|c|}
$\begin{array}{c}\text { Number of } \\
\text { first fruiting } \\
\text { node }\end{array}$ \\
\end{tabular} & $\begin{array}{c}\text { Length of } \\
\text { internode } \\
(\mathrm{cm})\end{array}$ & $\begin{array}{l}\text { Length of } \\
\text { fruit }(\mathrm{cm})\end{array}$ & $\begin{array}{c}\text { Width } \\
\text { of fruit } \\
\text { (cm) }\end{array}$ & $\begin{array}{c}\text { Number of } \\
\text { fruits per } \\
\text { plant }\end{array}$ & $\begin{array}{l}\text { Yield per } \\
\text { plant }(g)\end{array}$ \\
\hline \multirow{2}{*}{ Days to flowering } & $\mathrm{PC}$ & 1.000 & $-0.226 * *$ & 0.109 & -0.023 & 0.044 & -0.131 & $-0.173^{*}$ & -0.077 & -0.014 & -0.085 \\
\hline & $\mathrm{GC}$ & 1.000 & -0.081 & 0.128 & -0.012 & 0.111 & $-0.270 * *$ & -0.088 & -0.136 & -0.002 & -0.061 \\
\hline \multirow{2}{*}{ Plant height $(\mathrm{cm})$} & $\mathrm{PC}$ & & & -0.052 & $0.198^{*}$ & -0.019 & 0.096 & 0.100 & -0.068 & 0.047 & 0.071 \\
\hline & GC & & & -0.045 & $0.188^{*}$ & -0.019 & $0.178^{*}$ & -0.041 & -0.004 & 0.008 & 0.080 \\
\hline \multirow{2}{*}{ Number of branches per plant } & PC & & & & $0.205^{*}$ & -0.079 & 0.042 & 0.033 & \begin{tabular}{|l|}
0.119 \\
\end{tabular} & $0.190 *$ & 0.150 \\
\hline & GC & & & & $0.283 * *$ & -0.12 & 0.066 & 0.044 & \begin{tabular}{|l|}
0.135 \\
\end{tabular} & $0.252 * *$ & 0.158 \\
\hline \multirow{2}{*}{ Length of first fruiting node $(\mathrm{cm})$} & $\mathrm{PC}$ & & & & & 0.105 & -0.034 & 0.043 & \begin{tabular}{|l|}
0.146 \\
\end{tabular} & -0.016 & -0.083 \\
\hline & GC & & & & & 0.143 & -0.053 & 0.048 & $0.179 *$ & -0.072 & -0.064 \\
\hline \multirow{2}{*}{ Number of first fruiting node } & $\mathrm{PC}$ & & & & & & -0.039 & -0.143 & -0.052 & -0.017 & 0.039 \\
\hline & GC & & & & & & -0.006 & $-0.169 *$ & -0.053 & 0.010 & 0.010 \\
\hline \multirow{2}{*}{ Length of internode $(\mathrm{cm})$} & $\mathrm{PC}$ & & & & & & & 0.120 & 0.154 & $-0.191 *$ & -0.113 \\
\hline & GC & & & & & & & $0.180^{*}$ & 0.156 & $-0.208^{*}$ & -0.095 \\
\hline \multirow{2}{*}{ Length of fruit (cm) } & $\mathrm{PC}$ & & & & & & & & 0.112 & 0.007 & $-0.332 * *$ \\
\hline & GC & & & & & & & & $0.164 *$ & 0.003 & $-0.365 * *$ \\
\hline \multirow{2}{*}{ Width of fruit (cm) } & $\mathrm{PC}$ & & & & & & & & & 0.009 & 0.000 \\
\hline & $\mathrm{GC}$ & & & & & & & & & 0.035 & 0.000 \\
\hline \multirow{2}{*}{ Number of fruits per plant } & PC & & & & & & & & & & $0.660^{* *}$ \\
\hline & GC & & & & & & & & & & $0.707 * *$ \\
\hline \multirow{2}{*}{ Yield per plant (g) } & PC & & & & & & & & & & 1.000 \\
\hline & GC & & & & & & & & & & 1.000 \\
\hline
\end{tabular}

Table 2: Direct and Indirect effect of nine characters with fruit yield per plant at Phenotypic (PC) and Genotypic (GC) levels in okra.

\begin{tabular}{|c|c|c|c|c|c|c|c|c|c|c|c|}
\hline Characters & & $\begin{array}{c}\text { Days to } \\
\text { flowering }\end{array}$ & $\begin{array}{c}\text { Plant } \\
\text { height } \\
(\mathrm{cm})\end{array}$ & $\begin{array}{c}\text { Number of } \\
\text { branches } \\
\text { per plant }\end{array}$ & $\begin{array}{c}\text { Length of } \\
\text { first fruiting } \\
\text { node }(\mathrm{cm})\end{array}$ & $\begin{array}{c}\text { Number of } \\
\text { first fruiting } \\
\text { node }\end{array}$ & \begin{tabular}{|c} 
Length of \\
internode \\
(cm)
\end{tabular} & $\begin{array}{c}\text { Length } \\
\text { of fruit } \\
(\mathrm{cm})\end{array}$ & \begin{tabular}{|c|} 
Width \\
of fruit \\
(cm)
\end{tabular} & $\begin{array}{c}\text { Number of } \\
\text { fruits per } \\
\text { plant }\end{array}$ & $\begin{array}{l}\text { Yield per } \\
\text { plant (g) }\end{array}$ \\
\hline \multirow{2}{*}{ Days to flowering } & PC & -0.110 & -0.008 & -0.015 & 0.002 & 0.001 & -0.004 & 0.058 & 0.000 & -0.009 & -0.085 \\
\hline & GC & -0.052 & -0.002 & -0.004 & 0.000 & -0.007 & -0.029 & 0.035 & -0.001 & -0.001 & -0.061 \\
\hline \multirow{2}{*}{ Plant height $(\mathrm{cm})$} & PC & 0.025 & 0.034 & 0.029 & -0.017 & 0.000 & 0.003 & -0.034 & 0.000 & 0.030 & 0.071 \\
\hline & GC & 0.004 & 0.021 & 0.010 & 0.002 & 0.001 & 0.019 & 0.017 & 0.000 & 0.006 & 0.080 \\
\hline \multirow{2}{*}{ Number of branches per plant } & $\mathrm{PC}$ & 0.016 & 0.010 & 0.099 & -0.014 & 0.001 & 0.000 & 0.025 & 0.000 & 0.013 & 0.150 \\
\hline & GC & -0.006 & -0.001 & -0.028 & 0.007 & 0.008 & 0.007 & -0.018 & 0.002 & 0.187 & 0.158 \\
\hline \multirow{2}{*}{ Length of first fruiting node $(\mathrm{cm})$} & $\mathrm{PC}$ & 0.003 & 0.007 & 0.017 & -0.085 & 0.001 & -0.001 & -0.015 & 0.000 & -0.010 & -0.083 \\
\hline & GC & 0.001 & 0.004 & 0.005 & 0.011 & -0.009 & -0.006 & -0.019 & 0.001 & -0.052 & -0.064 \\
\hline \multirow{2}{*}{ Number of first fruiting node } & $\mathrm{PC}$ & -0.005 & -0.001 & 0.004 & -0.009 & 0.014 & -0.001 & 0.048 & 0.000 & -0.011 & 0.039 \\
\hline & $\mathrm{GC}$ & -0.006 & 0.000 & 0.000 & 0.002 & -0.059 & -0.001 & 0.068 & 0.000 & 0.007 & 0.010 \\
\hline \multirow{2}{*}{ Length of internode $(\mathrm{cm})$} & $\mathrm{PC}$ & 0.015 & 0.003 & 0.001 & 0.003 & -0.001 & 0.029 & -0.040 & 0.000 & -0.123 & -0.113 \\
\hline & GC & 0.014 & 0.004 & 0.001 & -0.001 & 0.000 & 0.109 & -0.072 & 0.001 & -0.151 & -0.095 \\
\hline
\end{tabular}




\begin{tabular}{|c|c|c|c|c|c|c|c|c|c|c|c|}
\hline \multirow{2}{*}{ Length of fruit (cm) } & $\mathrm{PC}$ & 0.019 & 0.003 & -0.021 & -0.004 & -0.002 & 0.004 & -0.335 & 0.000 & 0.004 & $-0.332 * *$ \\
\hline & $\mathrm{GC}$ & 0.005 & -0.001 & -0.003 & 0.001 & 0.010 & 0.020 & -0.400 & 0.001 & 0.002 & $-0.365 * *$ \\
\hline \multirow{2}{*}{ Width of fruit $(\mathrm{cm})$} & $\mathrm{PC}$ & 0.009 & -0.002 & 0.035 & -0.012 & -0.001 & 0.005 & -0.037 & -0.001 & 0.006 & 0.000 \\
\hline & $\mathrm{GC}$ & 0.007 & 0.000 & 0.005 & 0.002 & 0.003 & 0.017 & -0.066 & 0.006 & 0.025 & 0.000 \\
\hline \multirow{2}{*}{ Number of fruits per plant } & $\mathrm{PC}$ & 0.002 & 0.002 & 0.020 & 0.001 & 0.000 & -0.006 & -0.002 & 0.000 & 0.643 & $0.660 * *$ \\
\hline & $\mathrm{GC}$ & 0.000 & 0.000 & 0.005 & -0.001 & -0.001 & -0.023 & -0.001 & 0.000 & 0.727 & $0.707 * *$ \\
\hline
\end{tabular}

\section{Conclusion}

The inter character correlation coefficients studies revealed that yield per plant have highest significant positive correlation with number of fruits per plant (0.660), number of fruits per plant with number of branches per plant (0.252), length of first fruiting node with number of branches per plant (0.283). While positive significant correlation obtained between width of fruit and length of first fruiting node (0.179), length of internode and plant height (0.178), length of first fruiting node and plant height $(0.188)$ and also with number of branches per plant $(0.283)$. The path coefficient analysis revealed that the significant positive direct effect on yield per plant was observed by number of fruits per plant (0.707), number of branches per plant (0.099), plant height (0.034), length of internode (0.029) and number of first fruiting node (0.014) indicating that these traits will be considered as main component of selection in a breeding programme for higher seed yield.

\section{References}

1. Balai TC, Maurya IB, Verma S, Kumar N. Correlation and path analysis in genotypes of okra [Abelmoschus esculentus (L.) Moench]. The Bioscan. 2014;9:799-802.

2. Camciuc M, Bessifre JM, Vilarem G, Gaset A. Volatile components in okra seed coat. Phytochemistry 1981;48:311-315

3. Dewey DR, Lu KH. A correlation and path coefficient analysis of components of crested wheat grains seed production. Agronomy Journal 1959;51:515-518.

4. Gopalan C, Sastri BVR, Balasubramanian SC. Nutritive Value of Indian Foods. National Institute of Nutrition, Siddamsetty Press, Hyderabad 1991, 48.

5. Johnson HW, Robinson HF, Comstock RE. Genotypic and phenotypic correlation in soybean and their implication in selection. Agronomy Journal 1955;47:417482.

6. Kang MS, Miller JD, Tai PP. Genetic and phenotypic path analyses and heritability in sugarcane. Crop Science 1983;23:643-647.

7. Kochhar SL. Tropical crops. Macmillan Publishers Ltd., London and Basingstoke 1986, 467.

8. Panse NG, Sukhatme PV. Statistical methods for agricultural workers. ICAR Publ 1967, 347.

9. Ramanjinappa VKH, Arunkumar KH, Ashok Hugar A, Shashibhaskar MS. Genetic variability in okra [Abelmoschus esculentus (L.) Moench]. Plant Archives 2011;11:435-437.

10. Savello P, Martin FW, Mill JM. Nutritional composition of okra seed meal. Agricultural Food Chemistry 1980;28:1163-1166.

11. Singh B, Goswami A. Correlation and path coefficient analysis in okra [Abelmoschus esculentus (L.) Moench]. Indian journal of Agricultural Science 2014;84:12621266.

12. Swamy BN, Singh AK, Sravanthi B, Singh BK. Correlation and path coefficient analysis studies for quantitative traits in okra [Abelmoschus esculentus (L.) Moench]. Environment and Ecology 2014;32:1767-1771.
13. Sharma RK, Prasad K. Genetic divergence, correlation and path coefficient analysis in okra [Abelmoschus esculentus (L.) Moench]. Indian Journal of Agricultural Research 2015;49:77-82

14. Umrao V, Sharma SK, Rajeev Kumar, Vijai Kumar, Sharma A. Genetic variability and divergence analysis in okra [Abelmoschus esculentus (L.) Moench]. Hort Flora Research Spectrum 2014;3:127-132.

15. Wright S. 1921. Correlation and causation. Journal of Agricultural Research 2014;20:557-587. 